\title{
Preservation of Damar Kurung through jewelry design
}

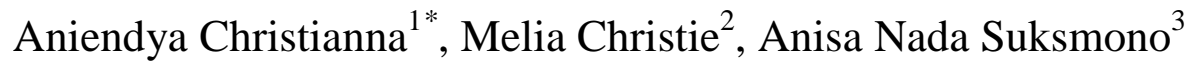 \\ ${ }^{1,2,3}$ Visual Communication Design, Faculty of Art and Design, Petra Christian University, Surabaya, Indonesia
}

\begin{abstract}
Towards the extinction of the Damar Kurung as a typical light tradition on the coast of Java, on October 4, 2017, the Ministry of Education and Culture of the Republic of Indonesia arranged the Damar Kurung as a National Intangible Cultural Heritage. This good news for many people who have been actively preserving Damar Kurung, so its existence as a legacy of local wisdom can be passed on to the younger generation. But the question is: whether in the era of the Industrial Revolution 4.0 the preservation of cultural heritage is still relevant? The writer's team implemented an alternative development of creativity that was inspired by the Damar Kurung's decoration into jewelry that was sale value and open to a wide market share. So far, there have been many creative products inspired by Damar Kurung, but they were limited to the middle (and lower) economic segments. Various levels of society need to appreciate Damar Kurung as a non-material cultural heritage. Thus, the legacy of the past can be recognized and appreciated by the people by adjusting the needs of the present. In the end, this efforts supported the development of creative industry based on local wisdom.
\end{abstract}

Key words: Damar Kurung, Jewelry, Creative Industry, Industrial Revolution 4.0, and Creativity.

\begin{abstract}
Abstrak
Menjelang kepunahan Damar Kurung sebagai tradisi cahaya khas derah pesisir Pulau Jawa, pada 4 Oktober 2017, Departemen Pendidikan dan Kebudayaan Republik Indonesia menetapkan Damar Kurung sebagai Warisan Budaya Takbenda Nasional. Ini adalah berita baik bagi individu/komunitas yang telah secara aktif melestarikan Damar Kurung, sehingga keberadaannya sebagai warisan kearifan lokal dapat ditemurunkan kepada generasi muda. Namun pertanyaannya adalah: apakah di era Revolusi Industri 4.0 pelestarian warisan budaya masih relevan?Tim penulis mengimplementasikan alternatif pengembangan kreativitas yang terinspirasi oleh ragam hias Damar Kurung menjadi perhiasan yang bernilai jual dan terbuka untuk pangsa pasar yang lebih luas. Sejauh ini, ada banyak produk kreatif yang terinspirasi oleh Damar Kurung, tetapi hanya terbatas pada segmen ekonomi menengah (dan bawah). Berbagai lapisan masyarakat perlu mengapresiasi Damar Kurung sebagai warisan budaya tak bendawi. Dengan demikian, warisan masa lalu dapat dikenali dan dihargai oleh orang-orang dengan menyesuaikan kebutuhan masa kini. Pada akhirnya, upaya ini mendukung pengembangan industri kreatif berbasis kearifan lokal.
\end{abstract}

Kata kunci: Damar Kurung, Perhiasan, Kreatif Industri, Revolusi Industri 4.0, dan Kreativitas.

\section{Introduction}

Javanese culture is closely related to symbols that teach about the wisdom of human life in living life: both to fellow human beings and God. Traditional ceremonies, advice, culinary, including fine arts and crafts, are some examples of symbols in Javanese culture. Damar Kurung is a typical Gresik lantern that has existed since the 16th century. Damar Kurung is traditional crafts created by artists with certain sociocultural backgrounds, her name is Masmundari (1904-
2005). Her aesthetic, artistic, social interaction and spiritual experiences influence the creative process of creating Damar Kurung.

Towards the extinction of the Damar Kurung, on October $4^{\text {th }}, 2017$, the Ministry of Education and Culture of the Republic Indonesia has been decided the Damar Kurung as a National Intangible Cultural Heritage (N.N., 2017). This is a good news is for many people who have been actively preserving Damar Kurung, so its existence as a legacy of local wisdom can be inherited on to the younger generation.

\footnotetext{
* Corresponding author, e-mail : aniendya@petra.ac.id
} 
But the question is: is in the era of the Industrial Revolution 4.0 the preservation of cultural heritage is still relevant in the midst of the production of popular products through high-speed sophisticated machines?

The 4.0 industrial revolution is expected to threaten human existence in the world of work. The prediction of threats posed by the industrial revolution 4.0 does sound scary because in the role of humans will be increasingly minimal. Jobs that do not require creativity, in-depth expertise and repetition of work will gradually disappear because the process is dominated by technology. But when the threat gets bigger, humans as creative beings should realize that they have to adapt. These challenges can be answered if humans utilize existing information to improve selfquality, creativity, and skills. This work ethic is very necessary for humans if they do not want to be eroded by time. Humans have creative power that can produce innovation. Through creativity, humans are able to produce artworks that are not necessarily technology and machines can do. Although some machines are said to have been able to do it, humans remain entities that have feelings and emotions, which until now has not been owned by technology.

Bill Holm states that the artifacts of the past need to be archived and their meanings published, before they are completely removed by the times (Holm, 1972). Since Masmundari (the last artist who preserved Damar Kurung), the family or community did not inherit expertise to continue the Damar Kurung conservation as Masmundari did. Damar Kurung that was made by Masmundari has been sold and distributed to collectors throughout Indonesia. Without good documentation and archiving, so becomes very difficult to track where it. The existence of Damar Kurung was fading slowly.

Based on the background description, the writer's team implemented an alternative development of creativity that was inspired by the Damar Kurung's decoration into jewelry that has a sale value and open to a wide market share. So far, there have been many creative products inspired by Damar Kurung, but they were limited to the middle (and lower) segments. Various levels of society, both from the bottom up to the top, need to recognize Damar Kurung as a nonmaterial cultural heritage. Thus, the legacy of the past can be recognized and appreciated by the people by adjusting the needs of the present. In the end, this efforts supported the development of creativity based on local wisdom to support economic improvement. To be able to bring up the creative industry based on local wisdom.

\section{Material and method}

The author has conducted a series of previous studies and publications related to Damar Kurung, namely The Role of Damar Kurung Lantern As A Time Signal Of Gresik Society in Journal of Sociotechnology ITB (Christianna, 2018a), The Representation of Javanese Women in Damar Kurung Painting in Journal of ISRA Mudra Denpasar (Christianna, 2018b), The Aesthetic Of Damar Kurung Painting in ARTESH ITB, 2018 and Batik Damar Kurung: Exploration of Women Performance in Java Culture in REKA UNS, 2018 along with 3 intellectual property rights of batik motifs. The series of studies that have been carried out leads to one goal which is to explore and identify the meaning and philosophy that contained on the Damar Kurung decoration. Damar Kurung decoration not only functions as decoration, but also contains Javanese cultural philosophy. The Damar Kurung decoration has 'recorded' the Gresik socio-cultural life since the time of Sunan Prapen (the last Sunan who ruled Giri Kedaton around the 16th century). Inevitably, the nuances of Hindu-Buddhist and Islamic influences dominate the Damar Kurung decoration.

Damar Kurung is a lantern made of oil paper with a bamboo frame that forms a 3-dimensional space. Each side of the paper is painted with various decorations that depict the Gresik culture. The unique thing about Damar Kurung is in organizing the field to tell a scene. Each scene is drawn with a special technique for sacred and profane scenes.

Masmundari has a naive, honest, plain, spontaneous but beautiful painting style. The drawing process starts from the middle-top, then moves right to fill the field. The fields specify different times and spaces in each sequence, with the 'read' direction from top to bottom-left to right (prasavya) (Toekio, 2007) for sacred stories, and from the bottom up-from any direction (right/left), for profane stories (such as daily activities, community and social issues). Overall, the pictures are painted without perspective, all objects (such as: humans, buildings, vehicles, animals and plants) are arranged sideways or stacked up and down. The object is drawn on top of another object, indicating that in reality the two objects are next to each other. Human figures are painted in styliation style and 'flat' styles similar with temple reliefs/wayang kulit/wayang beber.

\section{Jewelry Creative Industry in Indonesia}

During the Dutch colonial period, Indonesia reached its heyday in metal craft, because there was a cultural wisdom that developed from time to time. In 
Indonesia there are many metal industry centers, including Koto Gadang-West Sumatra, Kotagede in Yogyakarta, Bangil in Pasuruan and Celuk in Bali. Each region has its own uniqueness, for example jewelry and silver handicrafts in Kotagede, has a uniqueness in its carving motifs, which are characterized by the sultanate of Yogyakarta which has its own philosophical meaning. Most craftsmen run their businesses from generation to generation, using expertise and cultural heritage in their methods, designs and manufacturing. This indicates the high level of expertise and accuracy of Indonesian jewelry craftsmen. Another in Yogyakarta, another in Bali. Metal crafts in Bali also have their own characteristics. Balinese metal jewelry crafts tend to follow international tastes and trends. Based on data from the Central Bureau of Statistics (BPS), Bali metal jewelry exports reached $78 \%$ of Indonesia's total metal jewelry exports in 2011. Followed by DKI Jakarta, East Java and Yogyakarta with 19.42\%, $2.64 \%$ and 0 respectively, $02 \%$. However, in terms of value, Indonesia's exports of these metal products reached US \$ 76.12 million, an increase of $12.97 \%$. Two trade portal countries: Hong Kong and Singapore are the main export destination countries for jewelry products from Indonesia. In order, the main destination countries in the 10 destinations for Indonesian jewelry exports are, among others, the Netherlands, Thailand, Germany, Malaysia, Italy, Denmark and Turkey. Through Bisnisbali.com in January last year, it was revealed that Balinese jewelry was also popular because besides having its own characteristics, it also used handwork for most of its processes, which made it different from other countries.

The development of design is also an important point in the development of the metal jewelry industry in Indonesia, both domestically and abroad, because at this time the essence of metal jewelry has shifted towards design. Prices of raw materials that are released international are already open so that all interested parties can access them. Thus, the difference is the creativity and quality of the workmanship.

This is a qualitative research with a descriptive method that aims to describe the variety of Damar Kurung decoration, which is then classified as an inspiration for jewelry. Data collection methods taken through: (1) Literature study to find data about the history and Damar Kurung's decoration. (2) Documentation and field observations to find factual data about current jewelry trends and Damar Kurung's decoration style. Field data were obtained from observations at SME exhibitions held in Surabaya and surrounding areas. And (3) Interviews with craftsmen and jewelry artists in Surabaya, Bali and Sidoarjo.

This research was carried out for approximately 4 months which included the research/pre-production stage, the design/production stage and the postproduction stage: (1) The research stage, consists of Literature review, Damar Kurung's decoration review, and Classification and selection of Damar Kurung's decoration. (2) The design/production stage consists of explore Damar Kurung's decoration, explore and experiment metal material, jewelry design sketches, design analysis and aesthetic review, and design development and revision. And (3) The postproduction stage, consists of evaluate and revise prototypes and product photo shoot

Creative products designed are jewelry products consisting of various variants of necklaces, bracelets, rings and earrings. This creative product is a nickel plated brass experiment (electro plating technique). The development of the Damar Kurung's decoration into jewelry products is one of the conservation efforts to preserve Damar Kurung as a national intangible heritage. The output of this research is also expected to contribute to the designers and practitioners of art and or crafts in order to be able to utilize the local cultural heritage to improve the economy of the creative industry.

\section{Result and discussion}

The 4.0 industrial revolution contributed to the acceleration of production and dissemination of knowledge and information. Not only offering convenience, this era of technology is also leading to macro problems and macro opportunities. Existing developments will be an opportunity for individuals who have capital and readiness. But on the contrary, this development can also be a challenge for some individuals to survive. Difficulties will continue in the long run for those who lack the necessary skills and work experience. The nature of current technological developments shows that creative and innovative ways of thinking will be very needed (Ambrose \& Sternberg, 2016). Creativity is not only a matter of ability but also a desire to accept change and novelty (Márquez-ramos and Mourelle, 2018). Innovation is seen as the successful implementation of creative ideas.

Culture-based creative industry is an industry that refers to an industry that combines creativity, production and commercialization of creative content 
that becomes goods or services and inspired by local wisdom (Moore, 2014). Culture as one of the main sources of creativity has huge potential to be explored and developed further into commercial products. Culture which is the result of continuous creativity over a long period of time has become a very valuable legacy for generations afterwards. The overall richness of Indonesia culture is a source of creative industries, especially those related to arts and culture with a variety of ethnic values attached to them.

Batik, Wayang and Keris have been declared as Masterpieces of the Oral and Intangible Heritage of Humanity on October 2, 2009 by UNESCO. Intangible cultural heritage is all cultural relics that are abstract, cannot be touched physically (Sedyawati, 2003). Batik, Wayang and Keris are clearly visible and can be touched, but are instead declared as Masterpieces of the Oral and Intangible Heritage of Humanity. UNESCO and the Ministry of Education and Culture of the Republic of Indonesia consider that philosophical values and historical journeys are the soul of a cultural artifact. Although it is abstract, its existence is very important for the survival of a nation, because the intangible cultural heritage cannot be separated from its historical journey that forms the identity of a nation. Cultural artifacts can be damaged, extinct and physically lost, but the values therein will always persist. Therefore, it needs to be preserved and inherited.

On 4 October 2017, Damar Kurung was also declared a National Intangible Cultural Heritage by the Ministry of Education and Culture of the Republic Indonesia. Jakob Soemardjo stated that Damar Kurung had been known by Hindu-Buddhist communities in the past in Java and Bali (Ismoerdijahwati, 2009). Damar Kurung is a lantern that has a beautiful decoration and has a philosophical meaning. The wrapping paper is decorated with pictures that reflect the wisdom of Javanese life (coastal areas). Artists make them based on knowledge and skills that are inherited from their ancestors. Primadi Tabrani from ITB said that the decoration of Damar Kurung has a picture characteristic similar to the relief of the temple and Wayang beber. Damar Kurung has a sequence that consists of several scenes and moving objects in one space. Humans and animals are painted fully; nothing is closed up or zoom-in. Because each traditional artwork often contains symbolic and philosophical meanings, therefore there is a special drawing technique. So that Damar Kurung is not only visually beautiful, but also integrates with the traditional values that exist in society. Because it is abstract and easily lost over time, it requires preservation and education to the community so that Damar Kurung can still exist.

Unfortunately, the purpose of preserving Damar Kurung is contrary to public knowledge. The community understands Damar Kurung as a rectangular lantern. Some artists, communities and creative industries in Gresik have produced creative products inspired by the Damar Kurung lantern form, not from the decoration (Fig. 1). The products they have produced such as batik motifs and lanternshaped key chains. This gap can be an obstacle in efforts to preserve Damar Kurung. To anticipate the increasingly widespread misunderstanding about the preservation of Damar Kurung, proper education is needed for the community.

Primadi Tabrani (1969-1991) found a typical Nusantara drawing system that was not yet known in Western visual arts education, that is RWD (RuangWaktu-Datar). RWD is a solution when flat area/paper/cave's wall/etc (which does not have a dimension of time, only has dimensions of spacelength and width) is able to describe a continuous event (dimension of time). The RWD concept is the embodiment of Einstein's time relativity theory (Tabrani, 2000), where time and space cannot be separated time and space are pairs that cannot be separated. Every object in nature has its own space and time that is not exactly the same as each other, but these objects can be together become part of a theme. There are various directions, various distances, and various times in the RWD concept, allowing an image to tell a story.
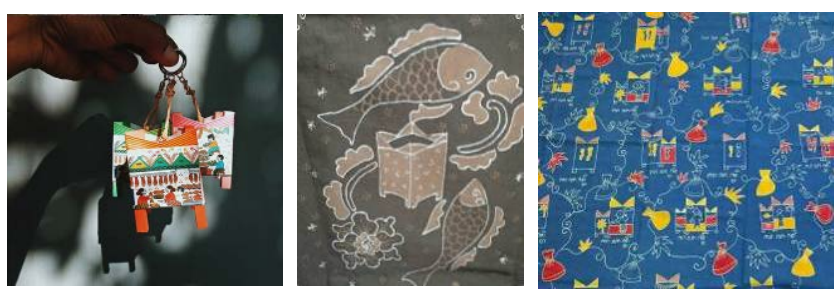

Fig. 1. Creative products that already exist in Gresik (key chain and batik)
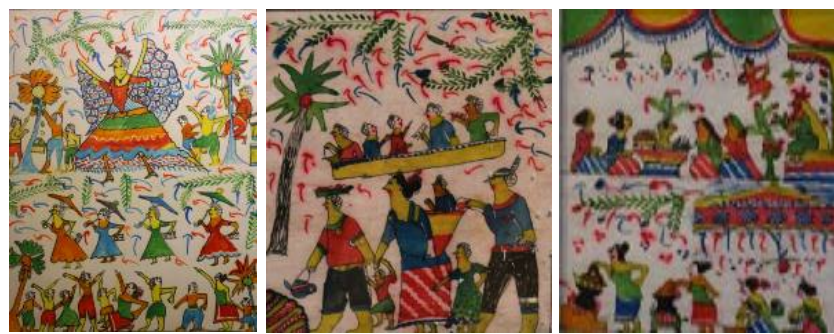

Fig. 2. Damar Kurung's Decoration 
The RWD concept is used by prehistoric/primitive paintings in the cave. When the letters began to develop, the paintings in the cave began to shift to the stone walls of the temple into reliefs. The RWD concept has dominated traditional artworks, such as Egyptian reliefs, Chinese, Japanese paintings, wayang kulit, wayang beber and reliefs on Indonesian HinduBuddhist temples. Because it is consist of several scenes and moving objects in one space.

Knowledge about Damar Kurung decoration can be disseminated not only through school classes, conventional cultural seminars or papers with lengthy explanations. Damar Kurung decoration that contains unique techniques and philosophies can be realized through creative products (Fig. 2). One of them is Gresik's jewelry designs. Jewelry like this has never existed in Gresik or in the surrounding city. Most creative industries produce products that are inspired by lanterns, not its decoration. These products are sold in souvenir shops at affordable prices for the middle-to-lower class. Jewelry inspired by the decoration of Damar Kurung can open opportunities for a wide market share to middle-up consumers. Although inspired by past cultural heritage, but can look elegant, according to current and future market tastes. This jewelry uses forms that have been distilled and deformed, but still do not lose their characteristics.

The jewelry design is based on the Damar Kurung decoration findings, which are about Javanese women and bandeng (milkfish). Sketches are made in actual size and consider the process of cutting brass plates. So that the design details that are too small must be removed.

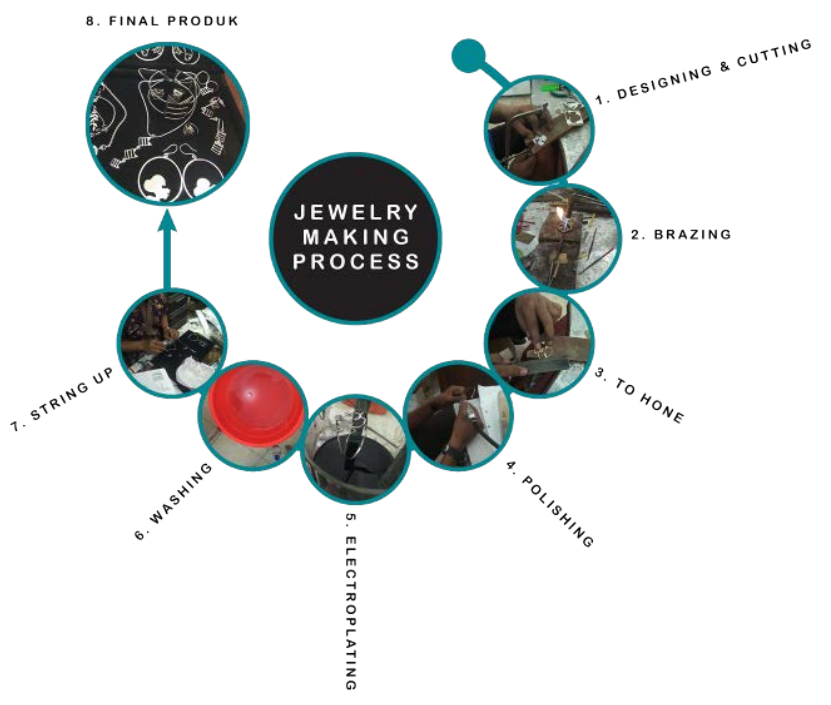

Fig. 3. Steps of Making Jewelry
Jewelry designs that have been made, are printed on paper in actual sizes. Then the paper was affixed to the brass plate which would become the raw material for jewelry. Brass plates are cut using a special saw in accordance with the shape of the jewelry. High patience and accuracy are needed in this process. Because of its small size and easily broken if wrong in the cutting process. In certain forms of jewelry needed a connection so that the desired shape can be obtained. Therefore desoldering process is needed, which uses a mixture of silver and brass. Desoldering uses a special tool that can melt silver to liquid such as glue to attach brass to one another. After the appropriate form is obtained, the next step is hone. Especially on uneven and rough stained results. Polishing is needed to obtain a completely flat and smooth metal surface.Polishing uses sandpaper with a certain degree of roughness. Polishing is useful for brightening metals before electroplating. Polishing uses a machine whose edges are given a soft cloth. The more polished the more shiny. Before the electroplating process, jewelry is immersed in a degresing solution that has been electrified using stainless metal for approximately 1 minute. Then dip it in distilling water for about 5 seconds. Then into H2S04 for 5-10 seconds. The immersion stage into aquades and $\mathrm{H} 2 \mathrm{~S} 04$ is repeated 2-3 times. To obtain metals that are completely clean of impurities, oil and other metals (residual stained). Before electroplating, jewelry must be dry and clean. Clean using a soft dry cloth. To carry out electroplating requires 6 solutions consisting of 6 ingredients: nickel sulfate, nickel chloride, nickel salt, universal nickel water, universal t/l initial, levelbriter888 maintance/polish in a separate glass vessel. The entire solution of the material is dissolved with distilled water and electrified using an adapter. The use of glass vessels to maximize the process of heating a solution of 60-70 degrees Celsius. It is not recommended to use metal vessels, because the solution will react to the metal, so the final result may not be as expected. Jewelry is dipped into each vessel in sequence for approximately 10 minutes. When all processes are finished, the jewelry is washed using a small brush and dishwashing soap. Until completely clean of the remaining solution during the process. Then dried using a soft cloth. The final process is stringing.

\section{Nyonyah Jewelry}

Nyonyah Jewelry (Fig. 4) is inspired by pictures of women in the Damar Kurung decoration. Most of Damar Kurung's decorations made by Masmundari depict the activities of Javanese women. Masmundari 
painted Damar Kurung based on observations from the surrounding environment. Javanese women are not seen as inferior and passive as most people judge. Described that women are active in all fields: domestic and public. Women are depicted in domestic activities, such as cooking in the kitchen, teaching children, childbirth, etc. In the public sector, women are portrayed by trading in markets, farming with men, fishing on the beach, celebrating independence day on the road, etc. Masmundari draws Javanese women with a distinctive: wearing jarik and kemben, barefoot and hair in a bun. While foreign women (because Masmundari experienced the Dutch and Japanese colonial era directly) are described as women who wear long dresses, curly hair, highheels, lipstick and wear jewelry (especially crowns, necklaces and earrings). All humans in the Damar Kurung decoration are depicted thoroughly from head to toe, naive, without perspective and side view. These visual characteristics are influenced by the visual characteristics of wayang kulit and temple reliefs from Hindu-Buddhist and Islamic cultures in the past.

\section{Bandeng Jewelry}

The Bandeng Jewelry (Fig. 5) is inspired by the milkfish market tradition that still continues today in Gresik. Bandeng market is a tradition that has been carried down for generations in the coastal area of Gresik. Bandeng market is an acculturation of Islamic culture with maritime culture, which only happens once a year. The bandeng market is usually held on the 29th night of the month of Ramadan, or two days before Idul Fitri, aims to welcom the night of takbiran or to enliven the largest Muslim holiday. According to Grisee Tempo Doeloe, bandeng market itself originated from Sunan Giri (one of the leading members of the Wali Songo) who spearheaded this bandeng market tradition to improve the economy of the local people based on the potential of natural resources. Around the 15th century Sunan Giri helped the people's economy by marketing the results of Gresik's natural resources through trade.

In Javanese culture which is full of symbols to analogize the value of life, bandeng is used as one of the complementary elements of tumpeng rice.

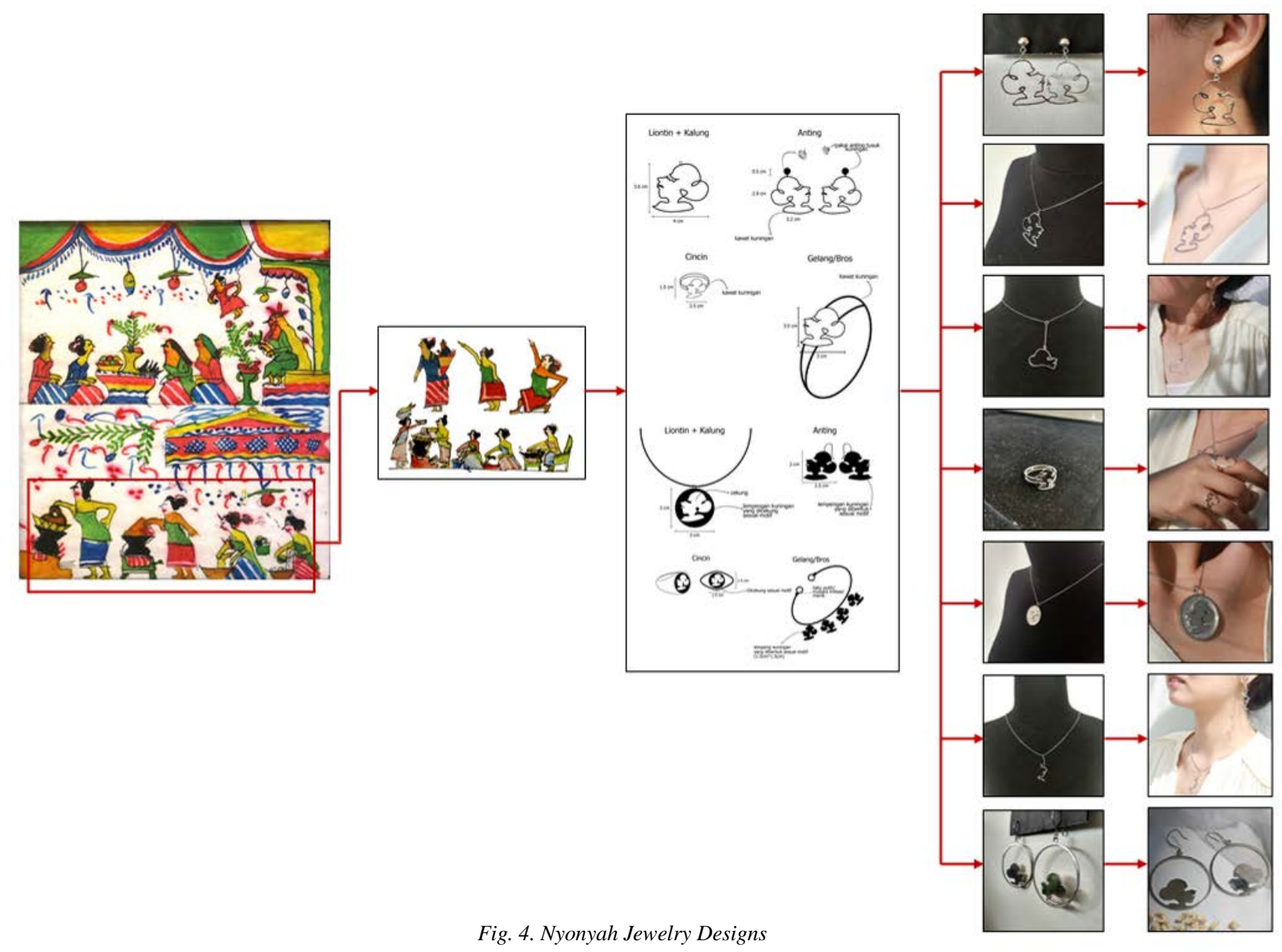




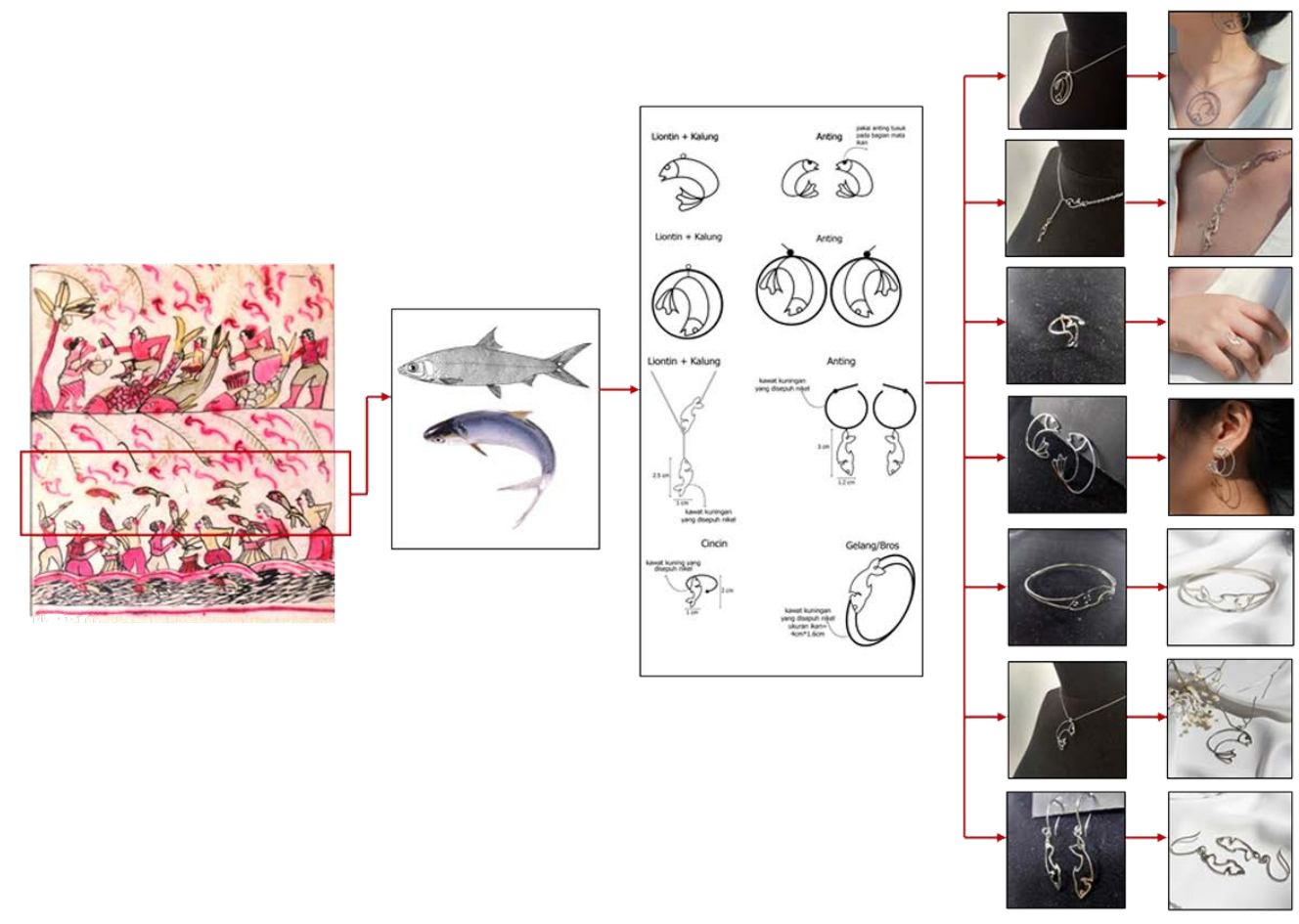

Fig. 5.Bandeng JewelryDesigns

Tumpeng rice is offerings that are used by Javanese people when performing certain prayers/rituals. the rice has been colored yellow with natural dyes (usually from turmeric) is formed conical with side dishes that complement the surroundings. Usually side dishes that complement tumpeng rice are local produce (both those that grow from the ground, and those that are obtained from the waters). Chicken, urap vegetables, eggs, red chili and seafood such as bandeng, lele or ikan teri are widely used to supplement tumpeng rice. According to Sumarjo (2002) bandeng in Javanese philosophy symbolizes the amount of luck and prosperity, as much as the fine thorns in the bandeng's body.

\section{Conclusion}

The 4.0 industrial revolution is expected to threaten human existence in the world of work. But when the threat gets bigger, humans as creative beings should realize that they have to adapt. These challenges can be answered if humans as a resource can utilize existing information resources to improve selfquality, creativity, and skills. It is also creativity that makes humans able to produce works of art that are not necessarily technology and machines capable of doing. Although some machines are said to have been able to do it, humans remain entities that have feelings and emotions, which until now has not been owned by technology.
Nyonyah Jewelry and Bandeng Jewelry are alternative development of creativity that was inspired by the decoration of Damar Kurung became jewelry that has a sale value and was open to a wide market. So far, there are many creative products inspired by Damar Kurung, but they are limited to the middle (and lower) economic segments. Various levels of society need to respect Damar Kurung as a nonmaterial cultural heritage. Thus, the legacy of the past can be recognized and appreciated by people with adjusting the needs of the present. In the end, this effort supports the development of creative industries based on local wisdom. This jewelry does not only contain selling values and aesthetic values, but also contains philosophical values that need to be preserved.

\section{References}

Ambrose, D., \& Sternberg, R. J. (2016). Creative Intelligence in the 21st Century Grappling with Enormous Problems and Huge Opportunities. Sense Publishers .

Christianna, Aniendya. (2018a). The Role Of Damar Kurung Lantern As A Time Signal Of Gresik Society. Jurnal SOSIOTEKNOLOGI Vol 17, No 1 (2018) p 65-73

Christianna, Aniendya. (2018b). The Representation Of Javanese Women In Damar Kurung Painting Gresik. MUDRA Journal of Art and Culture Vol. 33, No. 3, September 2018295 - 301.

Creswell, J. W. (2014). Research Design: Qualitative, Quantitative, and Mixed Methods Approaches (4th ed.). California: SAGE Publications, Inc. 
https://doi.org/10.1007/s13398-014-0173-7.2

Holm, Bill. (1972). Northwest Coast Indian Art an Analysis of Form. Seattle and London: University of Washington Press.

Ismoerdijahwati, Ika. (2009). Damar Kurung dari Masa ke Masa . Surabaya: Dewan Kesenian Surabaya.

Márquez-ramos, L., \& Mourelle, E. (2018). On the relationship between society and higher education: what path should we take? Distance Education, 7919, 1-18. https://doi.org/10.1080/01587919.2018.1436401

Moore, I.. (2014). Cultural and Creative Industries Concept-A Historical Perspective. Procedia Social and Behavioral Sciences 110. 738-746.

N.N. (2017) Damar Kurung diakui sebagai Warisan Budaya. http://www.kabargresik.com/damar-kurung-diakui-sebagaiwarisan-budaya/ Diakses 27/08/2019
N.N. (2019). Produk Perak Bali Miliki Keunggulan Desain dan Motif. http://bisnisbali.com/2019/01/20/produk-perak-balimiliki-keunggulan-desain-dan-motif/ Diakses 01/08/2019

Sedyawati, Edi. (2003). Warisan Budaya Takbenda: Masalahnya Kini di Indonesia. Depok: Pusat Penelitian Kemasyarakatan dan Budaya Lembaga Penelitian Universitas Indonesia (PPKBLPUI).

Sumarjo, Jakob. (2002). Arkeologi Budaya Indonesia. Yogyakarta: Qalam.

Tabrani, Primadi. (2000). Bahasa Rupa Prosiding Kumpulan Naskah Acuan untuk Kuliah, ITB-Bandung: ITB.

Toekio, Soegeng. (2007). Kekriyaan Nusantara. Surakarta: ISI Press Surakarta. 